\title{
Correction to: Pharmacokinetic and Pharmacodynamic Modeling to Optimize the Dose of Vestronidase Alfa, an Enzyme Replacement Therapy for Treatment of Patients with Mucopolysaccharidosis Type VII: Results from Three Trials
}

Yulan $\mathrm{Qi}^{1,2} \cdot$ Kathleen McKeever $^{1} \cdot \mathrm{Julie}$ Taylor $^{1} \cdot$ Christine Haller $^{1} \cdot$ Wenjie Song $^{1,3} \cdot$ Simon A. Jones ${ }^{4} \cdot$ Jack Shi $^{1}$

Published online: 4 December 2018

(c) The Author(s) 2019

\section{Correction to: Clinical Pharmacokinetics https://doi.org/10.1007/s40262-018-0721-y}

Introduction section, para 3, lines $2-4$ which previously read:

In an open-label, phase I/II, dose-finding trial (ClinicalTrials.gov identifier: NCT02418455),...

should read:

In an open-label, phase I/II, dose-finding trial (ClinicalTrials.gov identifier: NCT01856218),...

The original article can be found online at https://doi.org/10.1007/ s40262-018-0721-y.

Yulan Qi

yulan.qi@gmail.com

1 Ultragenyx Pharmaceutical Inc., 60 Leveroni Court, Novato, CA 94949, USA

2 Present Address: BioMarin Pharmaceutical Inc., 105 Digital Dr., Novato, CA 94949, USA

3 Present Address: Ascendis Pharmaceutical Inc., 500 Emerson St., Palo Alto 94301, USA

4 Willink Unit, Manchester Centre for Genomic Medicine, Saint Mary's Hospital, Manchester and Academic Health Sciences Centre, Central Manchester University Hospitals NHS Foundation Trust, Manchester, UK
The original article was corrected.

Open Access This article is distributed under the terms of the Creative Commons Attribution-NonCommercial 4.0 International License (http://creativecommons.org/licenses/by-nc/4.0/), which permits any noncommercial use, distribution, and reproduction in any medium, provided you give appropriate credit to the original author(s) and the source, provide a link to the Creative Commons license, and indicate if changes were made. 